\title{
AFRICAN BAOBABS WITH A VERY LARGE NUMBER OF STEMS AND FALSE STEMS: RADIOCARBON INVESTIGATION OF THE BAOBAB OF WARANG
}

\author{
ADRIAN PATRUT' ${ }^{\mathrm{a}, *}$, SÉBASTIEN GARNAUD ${ }^{\mathrm{b}}$, OUMAR KA ${ }^{\mathrm{c}}$, \\ ROXANA T. PATRUT' ${ }^{d}$, TOMAS DIAGNE ${ }^{\mathrm{e}}$, DANIEL A. LOWY', \\ EDIT FORIZS ${ }^{a}$, JENŐ BODIS ${ }^{a}$, KARL F. VON REDEN ${ }^{9}$
}

\begin{abstract}
The article presents the AMS (accelerator mass spectrometry) radiocarbon dating results of the baobab of Warang, Senegal. The investigation of the baobab revealed that it consists of 18 partially fused stems, which represents the largest number of stems reported for an African baobab. Three stems build the ring that closes a false cavity, while 15 stems grow outside the ring. Seven wood samples were collected from the false cavity and from the outer part of other stems. The dating results evinced that the stems belong to four different generations, out of which the first generation is around 500 years old. We also documented the presence of false stems, which emerge from a large adjacent stem, are triangular in horizontal section and act as an anchor. The baobab of Warang possesses 12 ordinary stems and 6 false stems.
\end{abstract}

Keywords: AMS radiocarbon dating, Adansonia digitata, tropical trees, multiple stems, age determination, inner cavity.

a Babeş-Bolyai University, Faculty of Chemistry and Chemical Engineering, 11 Arany Janos, RO-400028, Cluj-Napoca, Romania

b INECOBA, 8 Charles Vaillant, 93600 Aulnay-sous-Bois, France

c Faculty of Sciences and Techniques, Cheikh Anta Diop University, Dakar, Senegal

d Babeş-Bolyai University, Faculty of Biology and Geology, 44 Gheorghe Bilascu, RO-400015, Cluj-Napoca, Romania

e African Chelonian Institute, P.O.Box 449, 33022 Ngaparou, Mbour, Senegal

${ }^{\mathrm{f}}$ Nova University, 5000 Dawes Ave., Alexandria, VA 22311, U.S.A.

g NOSAMS Facility, Dept. of Geology \& Geophysics, Woods Hole Oceanographic Institution, Woods Hole, MA 02543, U.S.A.

* Corresponding author: apatrut@gmail.com 


\section{INTRODUCTION}

The African baobab (Adansonia digitata L.), which belongs to the Bombacoideae, a subfamily of Malvaceae, is the best-known and the biggest of the nine Adansonia species [1-3]. The African baobab has a natural distribution in the savanna regions of mainland Africa between the latitudes $16^{\circ} \mathrm{N}$ and $26^{\circ} \mathrm{S}$. It is also found in African islands and outside Africa in tropical areas, where it has been introduced $[1,2,4-7]$.

In 2005, we started an in-depth research in order to elucidate several controversial aspects regarding the architecture, growth and age of the African baobab. The research is based on our approach which also allows to investigate and date standing and live specimens. This approach involves the AMS radiocarbon dating of small wood samples collected from inner cavities and/or from deep incisions/entrances in the stems, fractured stems and from the outer part/exterior of large baobabs $[8,9]$.

Due to the special ability of baobabs to produce stems periodically during their life cycle, over time they develop architectures of increasing complexity. The dating results have demonstrated that all large baobabs are multi-stemmed. We identified the open and closed ring-shaped structures, which are the most significant architectures that enable African baobabs to reach old ages and large sizes. We also disclosed for the first time the presence of false cavities, which are large natural empty spaces between fused stems that are disposed in a closed ring-shaped structure. The oldest investigated and dated $A$. digitata specimens were found to have ages greater than $2000 \mathrm{yr}$ [10-13]. Dated growth rings of several African baobab specimens, which may act as a proxy climate archive, were used for past climate reconstruction in southern Africa [14,15].

The scientific name Adansonia digitata honours Michel Adanson, the French naturalist and explorer who documented and descibed the African baobab in its native habitat after his voyage to Senegal from 1749 to 1754 . Even if Senegal possesses more baobab specimens than all countries from southern Africa, the number of significant surveys and scientific articles about the Senegalese baobabs was scarce over the past 50 years [16].

Here we present the investigation and the AMS radiocarbon dating results of the African baobab with the largest known number of stems, the baobab of Warang, Senegal.

\section{RESULTS AND DISCUSSION}

The baobab of Warang and its area. The large baobab is located in Warang village, at $7 \mathrm{~km}$ south of Mbour, in Thiès region, Senegal. The GPS coordinates of the tree are $14^{\circ} 22.250^{\prime} \mathrm{N}, 016^{\circ} 56.330^{\prime} \mathrm{W}$ and the altitude is $7 \mathrm{~m}$. Mean annual rainfall in the area is $496 \mathrm{~mm}$. 
The baobab of Warang has a maximum height of $22.1 \mathrm{~m}$, the circumference at breast height (cbh; at $1.30 \mathrm{~m}$ above ground level) is 28.69 $\mathrm{m}$ and the overall wood volume is around $250 \mathrm{~m}^{3}$ (Figures 1 and 2). It consists of 18 partially fused stems that can be relatively easily counted. Hence, it becomes the African baobab with the highest known number of stems. The baobab has a closed ring-shaped structure, with a false cavity defined by three stems, as well as other 15 additional stems. The false cavity is accessible via an opening that leads into a corridor delimited by two stems and then into the cavity. The false cavity is bell shaped, with a maximum height of $2.74 \mathrm{~m}$ and an ellipsoidal base with the axes of $2.02 \times 2.13 \mathrm{~m}$ (Figure 3). The horizontal canopy dimensions are $33.6 \times 29.1 \mathrm{~m}$.

Wood samples. Two wood samples (labelled 1,2) were collected from the walls of the false cavity. Other three samples (labelled 3-5) were collected from three different stems. Finally, two samples (labelled 6, 7) were collected from the deepest end/origin and from the middle of the largest false stem FS1. All samples were collected at convenient heights, between 0.96 and $1.28 \mathrm{~m}$.

A number of eight small pieces/segments, of the length of $0.001 \mathrm{~m}$ each, were extracted from determined positions of the seven samples. Seven segments (1b, 2a, 3a, 4a, 5a, 6a, 7a, 8a) are close to the calculated pith and/or point of maximum age of the corresponding stems, while one segment (1a) correspond to an intermediate position inside stem 1.

AMS results and calibrated ages. Radiocarbon dates of the eight segments are listed in Table 1. Radiocarbon dates and errors were rounded to the nearest year. The radiocarbon dates are expressed in ${ }^{14} \mathrm{C}$ yr $\mathrm{BP}$ (radiocarbon years before present, i.e., before the reference year AD 1950).

Calibrated (cal) ages, expressed in calendar years, are also disclosed in Table 1. The 1- $\sigma$ probability distribution was selected to derive calibrated age ranges. For all sample segments, the 1- $\sigma$ distribution is consistent with two, three or four ranges of calendar years. For these segments, the confidence interval of one range is considerably greater than that of the other(s); therefore, it was selected as the cal $A D$ range of the segment for the purpose of this discussion. For obtaining single calendar age values of sample segments, we derived a mean calendar age of each segment from the selected range (marked in bold). Calendar ages of segments represent the difference between AD 2017 and the mean value of the selected range, with the corresponding error. Calendar ages and errors were rounded to the nearest $5 \mathrm{yr}$. 


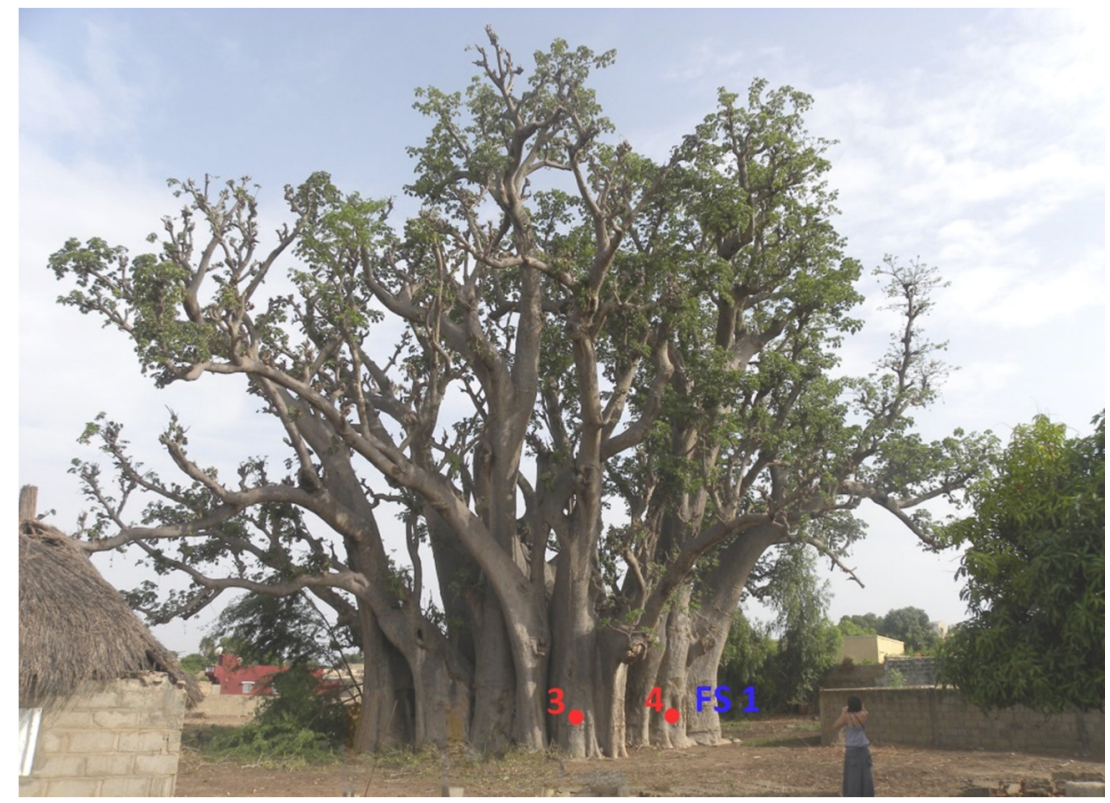

Figure 1. General view of the baobab of Warang taken from the west. The false stem 1 and the sampling positions 3 and 4 are marked.

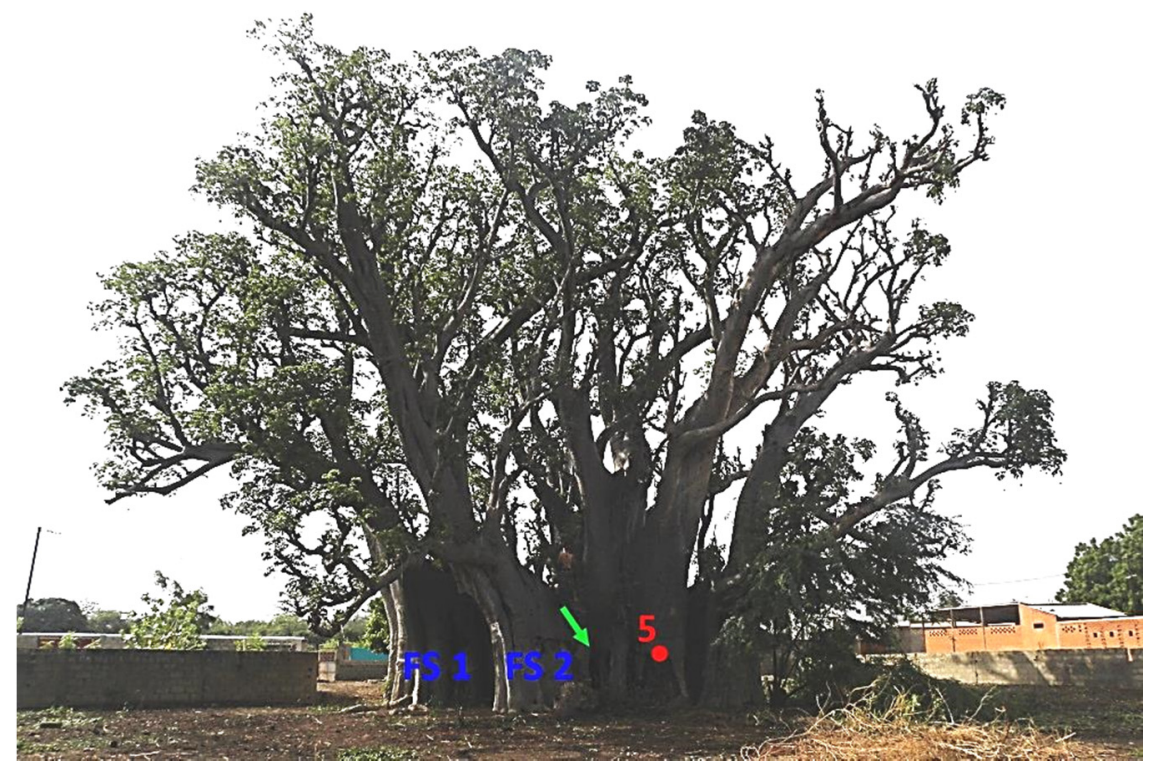

Figure 2. Another general view of the baobab of Warang taken from the east. The false stems 1 and 2 and the sampling position 5 are marked. 
AFRICAN BAOBABS WITH A VERY LARGE NUMBER OF STEMS AND FALSE STEMS:

Table 1. AMS Radiocarbon dating results and calibrated calendar ages of samples/segments collected from the baobab of Warang.

\begin{tabular}{|c|c|c|c|c|}
\hline $\begin{array}{c}\text { Sample } \\
\text { (Segment) }\end{array}$ & $\begin{array}{c}\text { Depth }^{1} \\
{\left[\text { height }^{2}\right]} \\
\left(10^{-2} \mathrm{~m}\right)\end{array}$ & $\begin{array}{c}\text { Radiocarbon date } \\
\text { [error] } \\
\left({ }^{14} \mathrm{C} \text { yr BP }\right)\end{array}$ & $\begin{array}{c}\text { Cal AD range } \\
1-\sigma \\
\text { [confidence interval] }\end{array}$ & $\begin{array}{c}\text { Sample age } \\
\text { [error] } \\
\text { (cal yr) }\end{array}$ \\
\hline $1 a$ & $\begin{array}{c}18 \\
{[96]}\end{array}$ & $113[ \pm 22]$ & $\begin{array}{c}1692-1710[10.6 \%] \\
1718-1728[6.2 \%] \\
1812-1890[45.7 \%] \\
1910-1920[5.7 \%]\end{array}$ & $165[ \pm 40]$ \\
\hline $1 \mathrm{~b}$ & $\begin{array}{c}40 \\
{[96]}\end{array}$ & $324[ \pm 25]$ & $\begin{array}{l}\mathbf{1 5 1 6 - 1 5 9 6}[\mathbf{5 5 . 2 \%}] \\
1618-1636[13.0 \%]\end{array}$ & $460[ \pm 40]$ \\
\hline $2 a$ & $\begin{array}{c}36 \\
{[104]}\end{array}$ & $308[ \pm 20]$ & $\begin{array}{l}\mathbf{1 5 2 2 - 1 5 7 4}[\mathbf{5 2 . 9 \%}] \\
1626-1642[15.3 \%]\end{array}$ & $470[ \pm 30]$ \\
\hline $3 a$ & $\begin{array}{c}44 \\
{[105]}\end{array}$ & $235[ \pm 25]$ & $\begin{array}{l}1649-1666 \text { [45.1\%] } \\
1784-1794[23.1 \%]\end{array}$ & $360[ \pm 10]$ \\
\hline $4 a$ & $\begin{array}{c}35 \\
{[110]}\end{array}$ & $110[ \pm 21]$ & $\begin{array}{c}1694-1710[10.7 \%] \\
1717-1726[6.2 \%] \\
1813-1890[46.6 \%] \\
1910-1917[4.7 \%]\end{array}$ & $165[ \pm 40]$ \\
\hline $5 a$ & $\begin{array}{c}54 \\
{[128]}\end{array}$ & $330[ \pm 20]$ & $\begin{array}{l}1512-1528[12.1 \%] \\
1544-1600[42.2 \%] \\
1616-1636[13.9 \%]\end{array}$ & $445[ \pm 30]$ \\
\hline $6 a$ & $\begin{array}{c}30 \\
{[110]}\end{array}$ & $262[ \pm 22]$ & $\begin{array}{c}1532-1536[3.4 \%] \\
\mathbf{1 6 3 6}-1664[64.8 \%]\end{array}$ & $365[ \pm 15]$ \\
\hline $7 a$ & $\begin{array}{c}30 \\
{[110]}\end{array}$ & $157[ \pm 24]$ & $\begin{array}{c}1670-1690[12.4 \%] \\
1729-1779[35.7 \%] \\
1798-1810[7.8 \%] \\
1925-1943[12.4 \%]\end{array}$ & $265[ \pm 25]$ \\
\hline
\end{tabular}

${ }^{1}$ Depth in the wood from the sampling point.

2 Height above ground level.

Dating results of samples (segments). The oldest dated segments, $1 \mathrm{~b}$ and $2 \mathrm{a}$, that originate from two stems that build the false cavity, are close to the estimated points of maximum age. Their radiocarbon dates of $324 \pm 25$ and $308 \pm 20$ BP correspond to calibrated ages of $460 \pm 40$ and $470 \pm 30$ calendar yr. The segment $5 \mathrm{a}$ has a comparable age, i.e., $330 \pm 20 \mathrm{BP}$, which corresponds to an age of $445 \pm 30$ calendar yr. The segment $3 a$ has a lower radiocarbon date of $235 \pm 25 \mathrm{BP}$ and a calibrated age of $360 \pm 10 \mathrm{yr}$. The radiocarbon date of $110 \pm 21 \mathrm{BP}$ of the youngest dated segment $4 \mathrm{a}$ corresponds to an age of only $165 \pm 40 \mathrm{yr}$. We also dated two segments $6 a$ and $7 \mathrm{a}$, which originate from samples collected from the deepest end/origin and from the middle of the false stem FS1. Their radiocarbon dates of $262 \pm 22$ and $157 \pm 24$ BP correspond to calibrated ages of $365 \pm 15$ and $265 \pm 25$ calendar yr. 


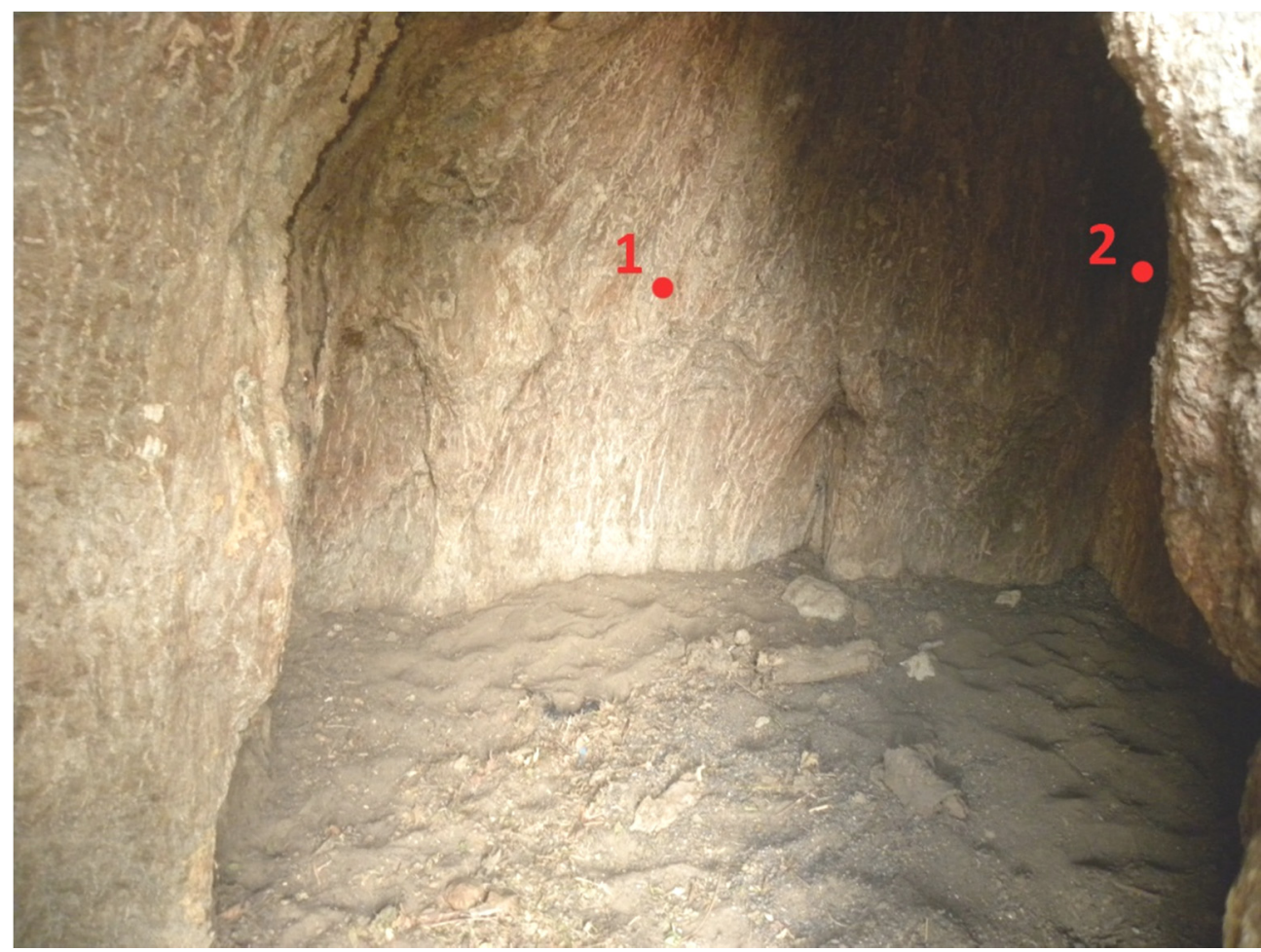

Figure 3. View of the false cavity which is defined by three stems. The sampling positions 1 and 2 are shown.

Ordinary and false stems. Prior to our research, the phenomenon of multiple stems among baobabs was mentioned only occasionally $[1,17]$. Visual observations suggest that typically only $15-25 \%$ of baobabs younger than 150-200 years have multiple stems. Nevertheless, radiocarbon results demonstrate that the vast majority of large and old baobabs are multistemmed. This is a consequence of the fact that, as baobabs age, singlestemmed specimens usually become multi-stemmed owing to the baobabs' ability to generate new stems periodically, such as other tree species produce branches. This phenomenon usually occurs naturally, when new stems periodically shoot from the roots or may emerge from fallen stems. In time, the new stems may fuse with older stem(s) or among them. Our investigations have revealed that all large baobabs, with a circumference over $16 \mathrm{~m}$ (corresponding to a formal diametre over $5 \mathrm{~m}$ ), are multi-stemmed. Therefore, any attempt to estimate the baobab's age by measuring its size/circumference is meaningless. 
The structure of old baobabs with fused stems can be determined by using radiocarbon dates and age sequences of samples collected from inner cavities and different areas of the trunk. In addition, one can perform a careful inspection of the multi-stemmed trunk, the canopy structure and the area/platform where the trunk divides into branches.

While often fused stems of multi-stemmed baobabs may prove to be difficult to identify, radiocarbon results indicate that several reported stems are in fact false stems. Hence, some large baobabs have peculiar structures that are triangular in horizontal section. Radiocarbon dating evinced that the oldest age can be found toward the upper contact with the larger adjacent stem, while the age decreases toward the opposite sharp extremity. This false stem, that plays the role of an anchor, is a special type of buttress, very different from the so-called buttress branch [1]. We named it also long triangular stem buttress (LTSB). The false stems emerge from a large trunk/stem and may reach horizontal lengths up to 3-5 $\mathrm{m}$. The upper part extends upward obliquely and branches out, while the lower part merges with the root system. Certain baobabs have two adjacent false stems disposed in V-shape, with an opening of $30-60^{\circ}$. Such false stems are able to offer a much better stability in sandy soils. The false stems are much more common in northern Africa than in southern Africa.

The baobab of Warang possesses 12 ordinary stems and 6 false stems. Two of them are long false stems diposed in V-shape, which are marked FS1 and FS2 (Figures 1, 2, 4). Their horizontal lengths are $3.90 \mathrm{~m}$ (FS1) and $2.47 \mathrm{~m}$ (FS2). The radiocarbon dating results of segments $6 a$ and $7 a$, extracted from the false stem FS1 (see Table 1), demonstrate that its oldest age is at the upper contact (6a) with the adjacent stem from which it emerged.

Age of the baobab of Warang. The ages of the oldest dated segments, $1 \mathrm{~b}, 2 \mathrm{a}$ and $5 \mathrm{a}$, which originate from three different stems, are between 445$470 \mathrm{yr}$. These values suggest an age of $500 \pm 50 \mathrm{yr}$ for the oldest stems of the baobab of Warang. The ages of segments $3 a$ and 4a, i.e., 360 and 165 $\mathrm{yr}$, indicate the existence of two other generations of stems that may be 350400 and $150-200 \mathrm{yr}$ old. The age of segment 6a shows that the longest false stem FS1 belongs to the generation which is $350-400 \mathrm{yr}$ old. Other two stems of the baobab are much smaller and they seems to be up to $100 \mathrm{yr}$ old. However, these stems are too young for an accurately dating by AMS radiocarbon.

Observations. Ten years ago, this large baobab was on a vacant land of Warang village, only $300 \mathrm{~m}$ away from the ocean shore. Over time, it was surrounded by a fence; in 2014, a local resident built a house at only $20 \mathrm{~m}$ from the baobab, thereby damaging some roots. We strongly believe that the national and local authorities should take urgent action for protecting this unique baobab and for preventing any further damage. 


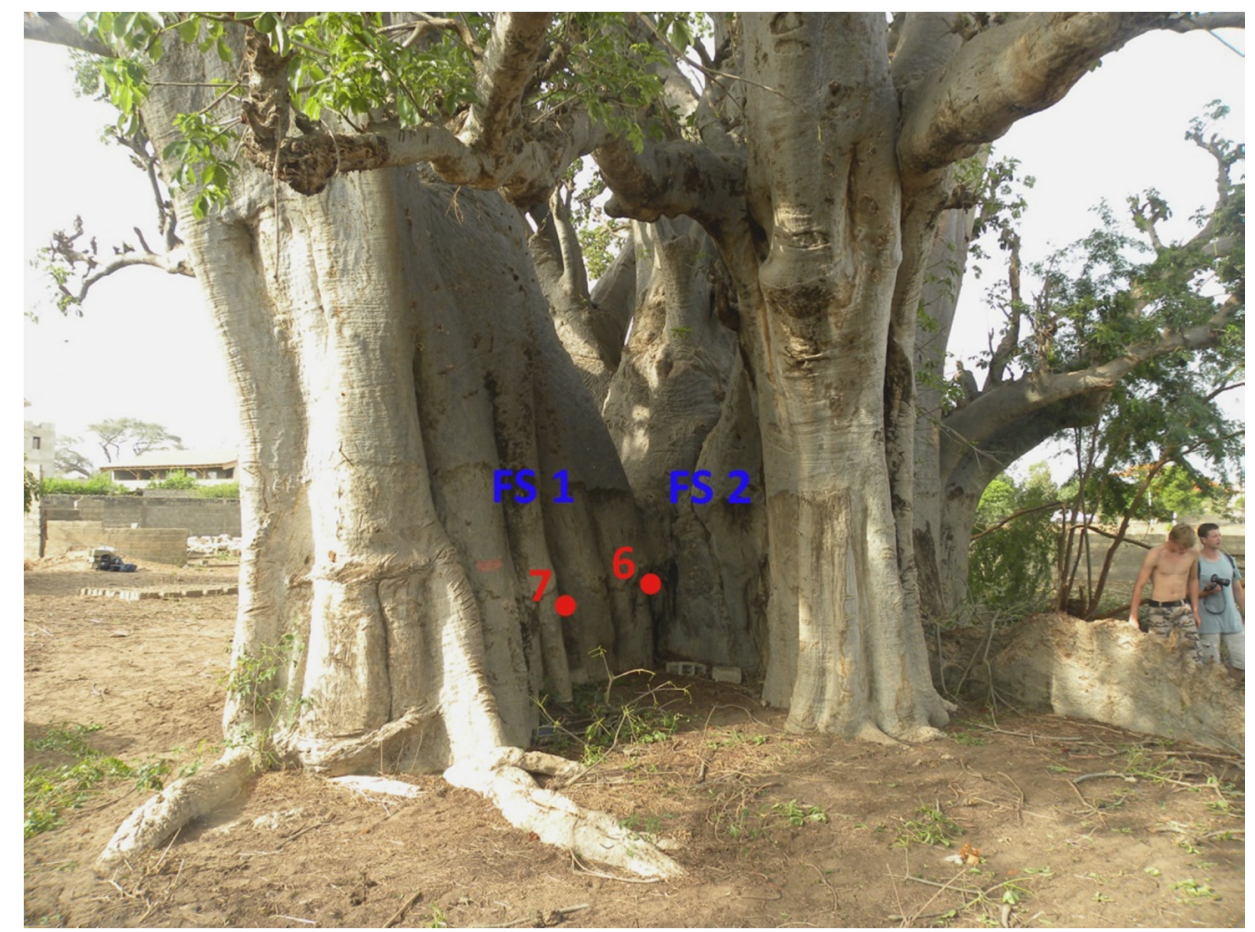

Figure 4. View of the two long false stems, FS1 and FS2, disposed in V-shape with an opening of $50^{\circ}$. The sampling positions 6 and 7 are shown.

One should also mention that, at a distance of only $103 \mathrm{~m}$ toward SW from the big baobab, stands another beautiful large baobab $\left(14^{\circ} 22.232^{\prime} \mathrm{N}\right.$, $016^{\circ} 56.378^{\prime} \mathrm{W} ; \mathrm{h}=24.2 \mathrm{~m}, \mathrm{cbh}=19.24 \mathrm{~m}$ ), which is located on a private property.

\section{CONCLUSIONS}

The research discloses the AMS radiocarbon investigation results of the stoutest Senegalese baobab, the baobab of Warang. The investigation of this large tree shows that it has a closed ring-shaped structure defined by three stems, with a false cavity inside, as well as 15 additional stems. Seven wood samples were collected from the false inner cavity and from the outer part of stems. The dating results indicate that the stems belong to three different generations, to which a very young generation can be added. 
The oldest stems, that belong to the first generation, are $500 \pm 50 \mathrm{yr}$ old. We documented for the first time the existence of false stems, which emerge from a larger adjacent stem. False stems, which are triangular in horizontal section, play the role of an anchor and offer a better stability, especially in sandy soils. The baobab of Warang has 12 ordinary stems and 6 false stems.

\section{EXPERIMENTAL SECTION}

\section{Sample collection}

The seven wood samples were collected with a Haglöf $\mathrm{CH} 600$ increment borer $(0.80 \mathrm{~m}$ long, $0.0054 \mathrm{~m}$ inner diametre). A number of eight tiny pieces/ segments of the length of $0.001 \mathrm{~m}$ were extracted from predetermined positions along the wood samples. The segments were processed and investigated by AMS radiocarbon dating.

\section{Sample preparation}

The standard acid-base-acid pretreatment method was used for removing soluble and mobile organic components. The pretreated samples were combusted to $\mathrm{CO}_{2}$ by using the closed tube combustion method. Then, $\mathrm{CO}_{2}$ was reduced to graphite on iron catalyst, under hydrogen atmosphere. Finally, the resulting graphite samples were analysed by AMS [4, 18, 19].

\section{AMS measurements}

AMS radiocarbon measurements were performed at the NOSAMS Facility of the Woods Hole Oceanographic Institution (Woods Hole, MA, U.S.A.) by using the Pelletron ${ }^{\circledR}$ Tandem 500 kV AMS system. The obtained fraction modern values, corrected for isotope fractionation with the normalized $\delta^{13} \mathrm{C}$ value of $-25 \%$, were ultimately converted to a radiocarbon date.

\section{Calibration}

Radiocarbon dates were converted into calendar ages with OxCal v4.2 for Windows [20], using the IntCal13 atmospheric set [21].

\section{ACKNOWLEDGMENTS}

Authors thank The Ministry of Environment and of Nature Protection of Senegal and its Direction of National Parks for authorising the investigation and sampling of the baobab of Warang. The research was funded by the Romanian Ministry of National Education CNCS-UEFISCDI under grant PN-II-ID-PCE-2013-76. 


\section{REFERENCES}

1. G.E. Wickens, P. Lowe, "The Baobabs: Pachycauls of Africa, Madagascar and Australia", Springer, Dordrecht, 2008.

2. D.A. Baum, Annals of the Missouri Botanical Garden, 1995, 82, 440.

3. J.D. Pettigrew, L.K. Bell, A. Bhagwandin, E. Grinan, N. Jillani, J. Meyer, E. Wabuyele, C.E. Vickers, Taxon, 2013, 61, 1240.

4. A. Patrut, K.F. von Reden, D.A. Lowy, A.H. Alberts, J.W. Pohlman, R. Wittmann, D. Gerlach, L. Xu, C.S. Mitchell, Tree Physiology, 2007, 27, 1569.

6. A. Patrut, D.H. Mayne, K.F. von Reden, D.A. Lowy, R. Van Pelt, A.P. McNichol, M.L. Roberts, D. Margineanu, Radiocarbon, 2010, 52, 717.

7. A. Patrut, R.T. Patrut, L. Rakosy, J. Bodis, D.A. Lowy, E. Forizs, K.F. von Reden, Studia UBB Chemia, 2016, LXI, 4, 21.

8. A. Patrut, D.H. Mayne, K.F. von Reden, D.A. Lowy, S. Venter, A.P. McNichol, M.L. Roberts, D. Margineanu, Radiocarbon, 2010, 52, 727.

8. A. Patrut, K.F. von Reden, R. Van Pelt, D.H. Mayne, D.A. Lowy, D. Margineanu, Annals of Forest Science, 2011, 68, 993.

9. A. Patrut, S. Woodborne, K.F. von Reden, G. Hall, M. Hofmeyr, D. Lowy, R.T. Patrut, PLoS ONE, 2015, 10(1), e0117193, doi: 10.1371/journal.pone.0117193.

10. A. Patrut, K.F. von Reden, D.H. Mayne, D.A. Lowy, R.T. Patrut, Nuclear Instruments and Methods in Physics Research Section B, 2013, 294, 622.

11. A. Patrut, S. Woodborne, R.T. Patrut, G. Hall, L. Rakosy, K.F. von Reden, D. Lowy, D. Margineanu, Studia UBB Chemia, 2015, LX, 4, 7.

12. A. Patrut, L. Rakosy, R.T. Patrut, I.A. Ratiu, E. Forizs, D.A. Lowy, D. Margineanu, K.F. von Reden, Studia UBB Chemia, 2016, LXI, 4, 7.

13. A. Patrut, S. Woodborne, K.F. von Reden, G. Hall, R.T. Patrut, L. Rakosy, P. Danthu, J-M. Leong Pock-Tsy, D.A. Lowy, D. Margineanu, Radiocarbon, 2016, in press.

14. S. Woodborne, G. Hall, I. Robertson, A. Patrut, M. Rouault, N.J. Loader, M. Hofmeyr, PLOS ONE, 2015, 10(5), e0124202. doi: 10.1371/journal.pone.0124202.

15. S. Woodborne, P. Gandiwa, G. Hall, A. Patrut, J. Finch, PLoS ONE 2016, 11(7), e015936. doi:10.1371/journal.pone.0159361.

16. J.G. Adam, Notes Africaines, 1962, 94, 33.

17. N. Esterhuyse, J. von Breitenbach, H. Söhnge, "Remarkable Trees of South Africa", Briza, Pretoria, 2001.

18. A. Patrut, D.H. Mayne, K.F. von Reden, D.A. Lowy, S. Venter, A.P. McNichol, M.L. Roberts, D. Margineanu, Radiocarbon, 2010, 52, 727.

19. A. Patrut, S. Woodborne, K.F. von Reden, G. Hall, M. Hofmeyr, D. Lowy, R.T. Patrut, PLoS ONE, 2015, 10(1), e0117193, doi: 10.1371/journal.pone.0117193.

20. C. Bronk Ramsey, Radiocarbon, 2009, 51, 337.

21. P.J. Reimer, E. Bard, A. Bayliss, J.W. Beck, P.G. Blackwell, C. Bronk Ramsey, C.E. Buck, H. Cheng, R. Lawrence Edwards, M. Friedrich, P.M. Grootes, T.P. Guilderson, H. Haflidason, I. Hajdas, C. Hatté, T.J. Heaton, D.L. Hoffmann, A.G. Hogg, K.A. Hughen, K.F. Kaiser, B. Kromer, S.W. Manning, M. Niu, R.W. Reimer, D.A. Richards, E.M. Scott, J.R. Southon, R.A. Staff, C.S.M. Turney, J. van der Plicht, Radiocarbon, 2013, 55, 1869. 